\title{
RELATIONSHIP BETWEEN HEPATIC COPPER CONCENTRATION AND LIVER ENZYMES ACTIVITY LEVELS IN BUFFALOES
}

\author{
EMAN M. ABD-EL NASER \\ Biochemistry and Nutritional Deficiency Diseases Department, \\ Animal Health Research Institute, Assiut Branch.
}

Received: 5 June 2016;

Accepted: 29 June 2016

\begin{abstract}
This study was conducted on 35 buffalo calves, which were randomly collected from a buffalo farm. All calves were classified according to the determination of hepatic and serum $\mathrm{Cu}$ concentration. (10) of them considered as a control group, while the rest (25) considered as cu accumulated group. All calves were slaughtered in Bani Adi slaughter house (Assiut, Egypt). Blood and liver samples were collected during ordinary slaughter of the animals. Serum samples used for determination of serum copper concentration, ceruloplasmin (CP) activity, and hepatic enzyme activities (AST and GGT).Cu concentration was determined in the liver samples and feed stuffs. Results showed that the mean value of both AST and GGT enzymes activity were significant $(\mathrm{p}<0.01)$ and $(\mathrm{p}<$ 0.05 ) increased in the cu accumulated group than the control one. The mean values of serum cu and hepatic cu were significant $(\mathrm{p}<0.01)$ increase in the cu accumulated group than the control group and also for molybdenum while for cereloplasmin was non-significant. The mean value of cu concentration in barseem, wheat straw and concentrates were evaluated. Significant correlation between hepatic $\mathrm{Cu}$ accumulation, serum AST activity and serum GGT activity were recorded in this study. Analysis of $\mathrm{Cu}$ content in the liver with determination of both AST and GGT enzymes activity is probably the best diagnostic tool currently available for assessing the risk of increase cu accumulation.
\end{abstract}

Key words: Copper, AST, GGT, hepatic cu accumulation, cereloplasmin

\section{INTRODUCTION}

Copper $(\mathrm{Cu})$ is one of the essential and important trace elements for the normal health and growth of animals (Rucker et al., 2008). Serum copper and other biochemical variables have limited diagnostic value in diagnosis of early hepatic copper accumulation. Some researchers concluded that the most reliable factor in diagnosing early accumulation of copper by determination of the serum activates of aspartate amino transferase (AST) and gamma glutamyle transferase (GGT) (Lo'pez-Alonso et al., 2006).

The most common tissue analyzed for mineral content is liver, as it is the primary storage organ for many of the essential minerals (Mc Dowell, and Arthington, 2005). Liver values are more informative and consistent as blood levels may remain normal for longer periods after liver trace elements levels commence to fall or increase indicating an early sign of trace elements deficiency or accumulation (Radostits et al., 2004). Liver copper concentration is

Corresponding author: Dr. EMAN M. ABD-EL NASER

E-mail address: eman_191069@yahoo.com

Present address: Biochemistry and Nutritional Deficiency Diseases Department, Animal Health Research Institute, Assiut Branch. the best indicator of copper status and is the standard to compare the performance of any test used for detect copper overload. (El-salam et al., 2013).

Liver $\mathrm{Cu}$ concentration that seemingly could be associated with subclinical chronic $\mathrm{Cu}$ toxicities in cattle has been observed in many countries where $\mathrm{Cu}$ supplements are given at concentration that is well above requirements, (Adei and Forson-Adaboh, 2008 and Leontopoulos et al., 2015) or where there is contamination of pastures as a result of mining, industrial emissions, or use of organic wastes as fertilizer, also hepatic $\mathrm{Cu}$ concentration could be just above the normally accepted "safe" values (Lo'pezAlonso et al., 2000 and Tokarnia et al., 2000).

There is a clear need to identify markers of early changes, with a capacity to predict risk of $\mathrm{Cu}$ accumulation in the liver before actual tissue or functional damage develops. Acquisition of these markers should be noninvasive, or at least less invasive than liver biopsy, and the markers should function as a sensitive index of $\mathrm{Cu}$ accumulation even in the absence of substantial functional damage. (Speisky et al., 2003 and El-salam et al., 2013).

Hepatic enzyme activities, together with $\mathrm{Cu}$ concentration in blood, liver, and kidney, are among 
the most widely used clinical tools for diagnosis of chronic $\mathrm{Cu}$ toxicities, (Auza et al., 1999) because hepatic cell damage leads to a suddenrelease of hepatic enzymes into the blood during the stages of increase hepatic copper.

Ceruloplasmin $(\mathrm{Cp})$ is a metalloenzyme with oxidase activity that is associated with iron and copper homeostasis (Szczubiał et al., 2008). Each molecule of ceruloplasmin contains six to eight atoms of copper which influence its biological activity. Cereloplasmin has been used diagnostically to confirm copper deficiency (Laven and Livesey, 2007). Ceruloplasmin (Cp) functions include transportation of copper in the blood to various tissues, oxidizing minerals most notably iron and manganese, and scavenging oxygen radicals to protect cells. Copper is involved in the antioxidant system through its presence in several significant proteins. Copper is present most commonly in the proteins ceruloplasmin and superoxide dismutase (SOD). Ceruloplasmin activity is diminished or absent without sufficient copper (Gropper et al., 2005).

Large numbers of livestock in many parts of the world consume diets that do not meet the dietary requirements (Ogundiran et al., 2012 and Wang et al., 2013). Continued ingestion of diets that are deficient, imbalanced or excessively high in a mineral induces changes in the form of concentration of the mineral in the body tissues and fluids, so that it falls below or rises above the tolerable limits. In such circumstances biochemical lesions develop, physiological functions are affected adversely and structural disorders may arise (Suttle and Jones, 2000 and Moral et al., 2008). Many factors that alter copper metabolism influence copper accumulation by enhancing the absorption or retention of copper. Low levels of molybdenum or sulfate in the diet are important examples to decrease the absorption of $\mathrm{Cu}$. (Akhtar et al., 2007).

Identification of animals of $\mathrm{Cu}$ accumulation is important to avoid not only economic losses due to subsequent severe disease or death, but also to avoid subclinical disease, and to adapt $\mathrm{Cu}$ supplementation to physiologic needs. It also has been reported that dietary supplements leading to $\mathrm{Cu}$ accumulation in the liver at concentration only slightly above normal (around $125 \mathrm{mg} / \mathrm{kg}$ of wet weight) induce negative effects on animal performance, in terms of reduced feed intake and average daily gain (Engle and Spears, 2000).

The aim of the study reported here was to evaluate the suitability of serum AST and GGT activities as potential markers of hepatic $\mathrm{Cu}$ accumulation in buffalo calves.

\section{MATERIALS AND METHODS}

\section{Animals:}

A total number of 35 buffalo calves were included in this study. Which were randomly collected from Alhawatka buffalo farm during the period from August to December 2015.All animals were dewormed according to the farm records. All calves were classified according to the determination of hepatic and serum levels of copper (10) of them considered as a control and 25 consideredascu accumulated group. All calves slaughtered in a slaughter house, Assiut, Egypt.

\section{Blood Sampling}

Blood and liver samples were collected during ordinary slaughter of the animals.

For separation of serum samples, blood sample $(20 \mathrm{ml})$ was collected from each calfe from the jugular vein into plane tube without anticoagulants. The blood samples were left to clot, then centrifuged to provide non haemolysed serum and frozen at $-20^{\circ} \mathrm{C}$ until analysis. Serum samples used for determination of serum copper levels, ceruloplasmin (CP) activity, and hepatic enzyme activities (AST and GGT). Liver sample (about 100g) was taken from the caudal lobe of each calfe immediately after slaughter. Samples were placed on ice immediately after collection, and were transported to the laboratory for further preparation.

\section{Biochemical Assays:}

Serum $\mathrm{Cu}$, AST and GGT were measured spectrophotometrically by using biodiagnostic test kits. Serum molybdenum was determined by using an atomic absorption spectrophotometer.

The activity of ceruloplasmin was measured by Assay Max Ceruloplasmin ELISA Kit (Catalog No. EC4001-1 Assaypro) A polyclonal antibody specific for ceruloplasmin had been pre-coated into a specific microplate with removable strips. Ceruloplasmin in standards and samples were tested for copper using spectrophotometer (UV/ VIS spectrophotometer Optizem 3220 uv MECASYS Co., LTD, Korea).Competed with a biotinylated ceruloplasmin sandwiched by the immobilized antibody and streptavidin- peroxidase conjugate. All unbound material was then washed away and a peroxidase enzyme substrate was added. The color development was stopped and the intensity of the color was measured.

Liver samples: (one gram) were digested in a mixture of 2:1: 0.5 nitric acid (HNO, 65\%, Perchloric acid $\left(\mathrm{HCLO}_{4}, 60 \%\right)$ and sulphuric acid $\left(\mathrm{H}_{2} \mathrm{SO}_{4}, 97 \%\right)$ respectively. The samples were further diluted and aspirated into an atomic absorption spectrophotometer. 
Feed samples:

The animals were fed according to the farm strategy depended mainlyon green berseem (Trifolium Alexandrinum) as it is the commonly available during winterseason plus some concentrates mixture and wheat straw. The commercial concentrate mixturein this district was supplied by certain company and consisted of; undecrticated cotton seedcake; course wheat bran; crushed corn; rice kernel and polish and salt. Samples were collected from the farm before animals go to the slaughter house. Feed samples were dried, ashed and the HCl-insoluble ash was determined according to Marshal (1993).
Copper and molybdenumwere determined by atomic absorption spectrophotometer (AA-640, Shmadzu Co., Ltd, Japan). The preparation of ration for copper determination wasdone according to Hady (1986).

\section{Statistical analysis:}

Recorded data were analyzed statistically using analysis of variance (ANOVA). The statistical differences between means were estimated by Duncons Multiple Range test. The computation was facilitated by statistical package SPSS (2000).Association between hepatic $\mathrm{Cu}$ accumulation and each of the blood parameters analyzed was assessed using the Pearson correlation coefficient.

\section{RESULTS}

Table 1: Mean and standard error values of serum AST and GGT activities in buffalo calves.

\begin{tabular}{cccc}
\hline Parameter & Control group & cu accumulation group & P value \\
\hline AST (U/L) & $117 \pm 18$ & $131 \pm 28.2$ & $<0.001$ \\
\hline GGT (U/L) & 11 & 24 & $<0.050$ \\
\hline
\end{tabular}

Table 2: Mean value of serum and hepatic cu and serum cereloplasmin (CP).

\begin{tabular}{cccc}
\hline Analyte & Control group & cu accumulation group & P value \\
\hline Serum Cu (mg/L) & $\mathbf{0 . 3 8 4 \pm 0 . 1 1}$ & $\mathbf{0 . 9 2 3 \pm 0 . 1 7 5}$ & $<0.01$ \\
\hline $\begin{array}{c}\text { Hepatic cu } \\
\text { mg/kg wet weight }\end{array}$ & $69.2 \pm 5.4$ & $192.4 \pm 7$ & $<0.01$ \\
\hline Cereloplasmin (mg/L) & $134 \pm 1.9$ & $165 \pm 3.4$ & n.s \\
\hline Molybdenum (ug/dl) & $43.80 \pm 2.4$ & $36.71 \pm 1.9$ & $<0.05$ \\
\hline
\end{tabular}

n.s=non significance

Table 3: Mean value of copper in different feed stuffs on dry matter basis.

\begin{tabular}{ccc}
\hline Feed stuff & copper & Molybdenum \\
\hline Barseem $(\mathrm{mg} / \mathrm{kg})$ & $17.4 \pm 1.32$ & $3.31 \pm 0.15$ \\
\hline Wheat straw $(\mathrm{mg} / \mathrm{kg})$ & $5.6 \pm 0.41$ & $1.96 \pm 0.13$ \\
\hline Concentrates $(\mathrm{mg} / \mathrm{kg})$ & $11.8 \pm 0.98$ & $2.11 \pm 0.12$ \\
\hline
\end{tabular}

Table 4: Pearson's correlation between liver copper concentration, serum $\mathrm{Cu}, \mathrm{Cp}, \mathrm{AST}$, and GGT.

\begin{tabular}{ccc}
\hline Analyte & \multicolumn{2}{c}{ Hepatic Cu } \\
\cline { 2 - 3 } & Pearson's correlation & P \\
\hline Serum Cu (mg/L) & 0.141 & $<0.240$ \\
\hline Cp $(\mathbf{m g} / \mathrm{L})$ & $\mathbf{- 0 . 0 8 5}$ & $<0.427$ \\
\hline AST $(\mathbf{U} / \mathrm{L})$ & 0.261 & $<0.035$ \\
\hline GGT $(\mathbf{U} / \mathrm{L})$ & 0.269 & $<0.027$ \\
\hline
\end{tabular}


Table 5: Mean values of Serum $\mathrm{Cu}$, Hepatic $\mathrm{Cu}$, AST, and GGT in both groups.

\begin{tabular}{ccccc}
\hline & Serum Cu(mg/L) & $\begin{array}{c}\text { Hepatic Cu mg/kg wet } \\
\text { weight }\end{array}$ & AST(U/L) & GGT(U/L) \\
\hline Control group & $\mathbf{0 . 3 8 4 \pm 0 . 1 1}$ & $69.2 \pm 5.4$ & $117 \pm 18$ & 11 \\
\hline $\begin{array}{c}\text { cu accumulation } \\
\text { group }\end{array}$ & $\mathbf{0 . 9 2 3} \pm 0.175 * *$ & $192.4 \pm 7 * *$ & $131 \pm 28.2 * *$ & $24 *$ \\
\hline
\end{tabular}

** significance at $\mathrm{P}<0.01$ and * significance at $\mathrm{P}<0.05$.

\section{DISCUSSION}

The results in table (1) revealed that the mean value of AST and GGTenzymes activity in control buffalo calves were $117 \pm 18$ and $11 \mathrm{u} / \mathrm{l}$ while calves with hepatic $\mathrm{cu}$ accumulation showed a mean value $131 \pm 28.2$ and $24 \mathrm{u} / 1$. The mean value of both AST and GGTenzymes activity were significant $(\mathrm{p}<0.01)$ and $(\mathrm{p}<0.05)$ increase in the cu accumulated group than the control one. These results are in agreement with those reported by (Lo'pez-Alonso et al., 2006 and Antonio et al., 2008).

Several authors have postulated that hepatic enzymes may also be useful asearly markers during the longterm, subclinical phase of hepatic $\mathrm{Cu}$ accumulation (Humann-Ziehank et al., 2001 and Laven et al., 2004). On the basis of the fact that, during this silent phase, some cells undergo necrosis, leading to increases in enzyme activities in the blood.

Table (2) showed the serum and hepatic $\mathrm{Cu}$ concentrations and serum Cpconcentration in control group were $0.384 \pm 0.11 \mathrm{mg} / \mathrm{L}, 69.2 \pm 5.4 \mathrm{mg} / \mathrm{kg}$ wet weight and $134 \pm 1.9 \mathrm{mg} / \mathrm{L}$ while these values in the cu accumulated group were $0.923 \pm 0.175 \mathrm{mg} / \mathrm{L}$., $192.4 \pm 7$ $\mathrm{mg} / \mathrm{kg}$ wet weight and $165 \pm 3.4 \mathrm{mg} / \mathrm{L}$ respectively.

The mean value of serum cu and hepatic cu were significant $(\mathrm{p}<0.01)$ increase in the $\mathrm{cu}$ accumulated group than the control group. The mean value of serum molybdenum was significant $(\mathrm{p}<0.05)$ increase in the cu accumulated group than the control group while cereloplasmin was non-significant. These results are in agreement with those reported by (Bidewelland Livesey, 2002 and Lo'pez-Alonso et al., 2006).

Results of this study indicate that, in buffalo with moderate hepatic $\mathrm{Cu}$ accumulation, neither the serum cu nor CP concentration, (the 2 main parameters typically used in the diagnosis of $\mathrm{Cu}$ deficiency), (Tessman et al., 2001), are significantly associated with hepatic $\mathrm{Cu}$ concentration.

Table (3) the mean values of cu concentration in barseem, wheat straw and concentrates were $17.4 \pm 1.32,5.6 \pm 0.41$ and $11.8 \pm 0.98$ respectively. the mean values of molybdenum concentration in barseem, wheat straw and concentrates were $3.31 \pm 0.15,1.96 \pm 0.13$ and $2.11 \pm 0.12$ respectively.

Ingestion of quantities of $\mathrm{Cu}$ slightly higher than required may cause accumulation in the hepatic cells. Generally, the copper content of the different Egyptian feedstuffs was ranged between 4.5 and 16.7 $\mathrm{mg} / \mathrm{kg}$ confirming the adequacy of copper to satisfy the animal's requirement which on average is 10 $\mathrm{mg} / \mathrm{kg}$ established by Anonymous. (1996 and 2005) and Ogundiran et al. (2012), and more than the critical level reported by NRC (1984). Molybdenum contents in all fodders examined were adequate, where dietary requirement of molybdenum for cattle and buffaloes was $0.2-7 \mathrm{mg} / \mathrm{kg}$ (Church, 1988).

In fact, the trace elements concentrations for animals' in both serum and liver will therefore depend on the mineral contents of feed and forage, the level of dietary sources intake, and the availability of minerals (Kamalu et al., 2006; and Khan et al., 2007). Also many environmental and plant factors affect the mineral concentrations of forage plants; which include, species or strain, variety, soil type, the climatic conditions of different seasons during plant growth, stage of maturity of forage plants and other management practices (McDowell and Arthington, 2005 and Wang et al.,2013).

Table (4 and 5) showed significant correlation between hepatic $\mathrm{Cu}$ accumulation, serum AST activity and serum GGT activity, these results are in agreement with those reported by Blakley and Hamilton, 1985, Stoszed et al., 1986, Lo'pez-Alonso et al., 2006 and Antonio et al., 2008). These results indicated that hepatic $\mathrm{Cu}$ and $\mathrm{CP}$ concentrations are not correlated at either normal or high amounts of hepatic $\mathrm{Cu}$ accumulation. This is because, once the animal's liver reaches adequate $\mathrm{Cu}$ status, $\mathrm{CP}$ as well as $\mathrm{Cu}$-dependent enzymes such as superoxide dismutase in erythrocytes attain maximal activity that is not increased with further hepatic $\mathrm{Cu}$ accumulation (Baker et al., 1999 and Rock et al., 2000) in addition, $\mathrm{CP}$ values vary with factors, such as age and sex, (Fisher et al.,1990) and increase rapidly in response to factors other than $\mathrm{Cu}$ excess, such as exercise and various inflammatory and infection conditions. (Harris, 1997). 


\section{CONCLUSION}

Analysis of $\mathrm{Cu}$ content in the liver is probably the best diagnostic tool currently available for assessing the risk of increase cu accumulation. Hepatic biopsy specimens should be regularly obtained from animals at risk for increase $\mathrm{Cu}$ concentration (e.g., highly $\mathrm{Cu}$ supplemented diet or grazing in contaminated areas).

\section{REFERENCES}

Adei, E. and Forson-Adaboh, K. (2008): Toxic (Pb, $\mathrm{Cd}, \mathrm{Hg}$ ) and essential (Fe, $\mathrm{Cu}, \mathrm{Zn}, \mathrm{Mn}$ ) metal content of liver tissue of some domestic and bush animals in Ghana. Food Additives and Contaminants, 1 (2): 100-105.

Akhtar, M.Z.; Khan A.; Sarwar M. and Javaid A. (2007): Influence of soil and forage minerals on buffalo (Bubalusbubalis) Parturient Haemoglobinuria. Asian-Aust. J. Anim. Sci. vol. 20, No. 3:393-398.

Anonymous (1996): MAFF UK-Labelling of fresh meat and poultry survey. Food Surveillance Information Sheet (pp. 87).

Anonymous (2005): Commission Recommendation (EC) 1. of March 2005 concerning acoordinated programe for the official control of foodstuffs. L59. Official Journal of the European Union, 27-39.

Antonio H.H. Minervino; Raimundo A. Barre'toJu' nior; Genilson F. Queiroz; Selwyn A. Headley and Enrico L. Ortolani (2008): Predictive values of aspartate aminotransferase and gamma-glutamyltransferase for the hepatic accumulation of copper in cattle and buffalo. J Vet. Diagn Invest. 20:791-795

Auza, N.J.; Olson, W.G.; Murphy, M.J. and Linn, J.G. (1999): Diagnosis and treatment of copper toxicosis in ruminants. J. Am. Vet. Med. Assoc 214:1624-1628.

Baker, A.; Turkey, E. and Bonham, M.P. (1999): No effect of copper supplementation on biochemical markers of bone metabolism in healthy adults. Br J Nutr 82:283-290.

Bidewell, C. and Livesey, C. (2002): Copper poisoning: an emergingdisease in dairy cattle. State Vet. J. 12:16-19.

Blakley, B.R. and Hamilton, D.L. (1985): Ceruloplasmin as an indicator of copper status in cattle and sheep. Can J. Comp. Med. 49: 405-408.

Church, D.C. (1988): The ruminant animal digestive physiology and nutrition. Prentice Hall. Englewood Chiffs. new Jersey.

EI-Salam, N.M.A.; Ahmad, S.; Basir, A.; Rais, A.K.; Bibi, A.; Ullah, R. and Hussain, I. (2013): Distribution of heavy metals in the liver, kidney, heart, pancreas and meat of cow, buffalo, goat, sheep and chicken from kohat market Pakistan. Life Science Journal, 10 (7).
Engle, T.E. and Spears, J.W. (2000): Effects of dietary copper concentration and source on performance and copper status of growing and finishing steers. J. Anim Sci. 78:2446-2451.

Fisher, P.W.F.; La'bbe', M.R. and Giroux, A. (1990): Effects of age, smoking, drinking, exercise and estrogen use on indices of copper status in healthy adults. Nutr Res 10:1081-1090.

Gropper, S.S.; Smith, J. and Groff, J. (2005): Advanced Nutrition and Human Metabolism: Copper transport and uptake. 4th ed. Wadsworth. Belmont, CA. 449-451.

Hady, Maha, M. (1986): Role of micro elements in nutrition of water buffalo and its relation to production and animal health. Ph.D. Thesis, Faculty of veterinary Medicine, Cairo University, Egypt.

Harris E.D. (1997): Copper. In: Handbook of nutritionally essential mineral elements, eds., O9Dell BL, Sunde RA, pp. 231-273. New York, NY. Marcel Decker.

Humann-Ziehank, E.; Coenen, M.; Ganter, M. and Bickhardt, K. (2001): Long-term observation of subclinical chronic copper poisoning in two sheep breeds. J. Vet. Med. SerA-Physiol Pathol. Clin. Med. 48:429-439.

Khan, Z.I.; Ashraf, M. and Hussain, A. (2007): Evaluation of macro mineral contents of forages: influence of pasture and seasonal variation. Aust. J. Anim. Sci. 20, 6: 908.

Kamalu, T.N.; Okpe, G.C. and Williams, A. (2006): Mineral contents of extracellular fluids in camel and cattle in northeast Sahel region of Nigeria. Nigerian. Vet. J., 24: 13-20.

Laven, R.A.; Livesey, C.T.; Offer, N.W. and Fountain, D. (2004): Apparent subclinical hepatopathy due to excess copper intake in lactating Holstein cattle. Vet. Rec. 155:120-121.

Laven, R.A. and Livesey, C.T. (2007): An evaluation of the effect of clotting on the relationship between copper and cereloplasmin in bovine blood. Vet. J. 174: 400- 402

Leontopoulos, St.; Gougoulias, N.; Kantas, D.; Rokal. and Makridisch. (2015): Heavy Metal Accumulation in Animal Tissues and Internal Organs of Pigs Correlated with Feed Habits. Bulgarian Journal of Agricultural Science, 21 (No 3), 699-703.

Lo'pez-Alonso, M.; Benedito, J.L. and Miranda, M. (2000): The effect of pig farming on copper and zinc accumulation in cattlein Galicia (North-Western Spain). Vet. J. 160:259-266.

Lo'pez-Alonso, M.; Crespo, A. and Miranda, M. (2006): Assessment of some blood parameters as potential markers of hepatic copper accumulation in cattle. J. Vet. Diagn Invest $18: 71-75$.

Marshal, R.T. (1993): Standard Methods for Examination of Dairy Products. American 
Public Health Association Report, Washington, USA.

McDowell, L.R. and Arthington, J.D. (2005): Minerals for grazing ruminants in tropical regions of Florida, IFAS, Ganesville.

Moral, R.; Perez-Murcia, M.D.; Perez-Espinosa, A.; Moreno Caselles, J.; Paredes, G. and Rufete, B. (2008): Salinity, organic content, micronutrients and heavy metals in pig slurries from South-eastern Spain. Waste Management, 28: 367-371.

NRC (1984): Nutrient Requirements of Domestic animals, No. 4. Nutrient requirements ofBeefCattle.6th edition. National Research Council, Washington DC.

Ogundiran, M.; Ogundele, D.T.; Afolayan, P.G. and Osibanjo, O. (2012): Heavy metals levels in forage grasses, leachate and lactating cows reared around lead slag dumpsites in Nigeria. International Journal of Environmental Research, 6 (3): 695-702.

Radostits, O.M.; Gay, C.C.; Blood, D.C. and Hinchcliff, K.W. (2004): Veterinary Medicine, 9th Ed. (Baillier Tindall, London, Philadelphia, New york).

Rock, E.; Mazur, A.; Connor, J.M. (2000): The effect of copper supplementation on red blood cell oxidizability and plasma plasma antioxidants in middle-aged healthy volunteers. Free RadicBiol Med. 28:324-329.

Rucker, R.B.; Fascetti, A.J. and Keen, C.L. (2008): Trace minerals, chapter biochemistry of domestic animals, 6 thedn. Academic Press, London, pp. 663-693.

Speisky, H.; Navarro, P.; Cherian, M.G. and Jimenez, I. (2003): Copperbinding proteins in human erythrocytes: searching for poten tialbiomarkers of copper over-exposure. Biometals 16:113-123.

SPSS (2000): Sample Power Statistics, SPSS 11.5, Syntax Reference Guide for SPSS Base. SPSS Inc., 233 South Wacker Drive, Chicago.

Suttle, N.F. and Jones, D.J. (2000): Micronutrient imbalance, In: Diseases of Sheep, 3rd ed., Martin, W.B. and Aitken, I.D. ed., Blackwell Science, Oxford, Tokyo, Berlin. 332-344.

Stoszed, M.J.; Mika, P.G.; Oldfield, J.L. and Weswig, P.H. (1986): Influence of copper supplementation on blood and liver copper in cattle fed tall fescue or quack grass. J. Anim Sci 62:263-271.

Szczubiat, M.; Dabroweski, R.; Kankofer, M. and Bochniarz, M; Albera, (2008): Concentration of serum amyloid A and activity of ceruloplasmin in milk from cows with clinical and subclinical mastitis. Bull Vet. Inst. Pulawy, 52: 391-395

Tokarnia, C.H.; Dobereiner, J.; Peixoto, P.V. and Moraes, S.S. (2000): Outbreakof copper poisoning in cattle fed poultry litter. Vet. Hum Toxicol 42: 92-95.

Tessman, R.K.; Lakritz, J. and Tyler, J.W. (2001): Sensitivity and specificity of serum copper determination for detection of copperdeficiency in feeder calves. $\mathbf{J}$ Am Vet Med Assoc 218:756-760.

Wang, H.; Dong, Y.; Yang, Y.; Toor, G. and Zhang, $X$. (2013): Changes in heavy metal contents in animal feeds and manures in an intensive animal production region of China. Journal of Environmental Science, 25 (12): 2435-2442.

\section{العلاقه بين تركيز النحاس فى كبد الجاموس ومستوى نشاط انزيمات الكبا}

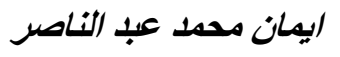

Email: eman_191069@yahoo.com

Assiut University web-site: www.aun.edu.eg

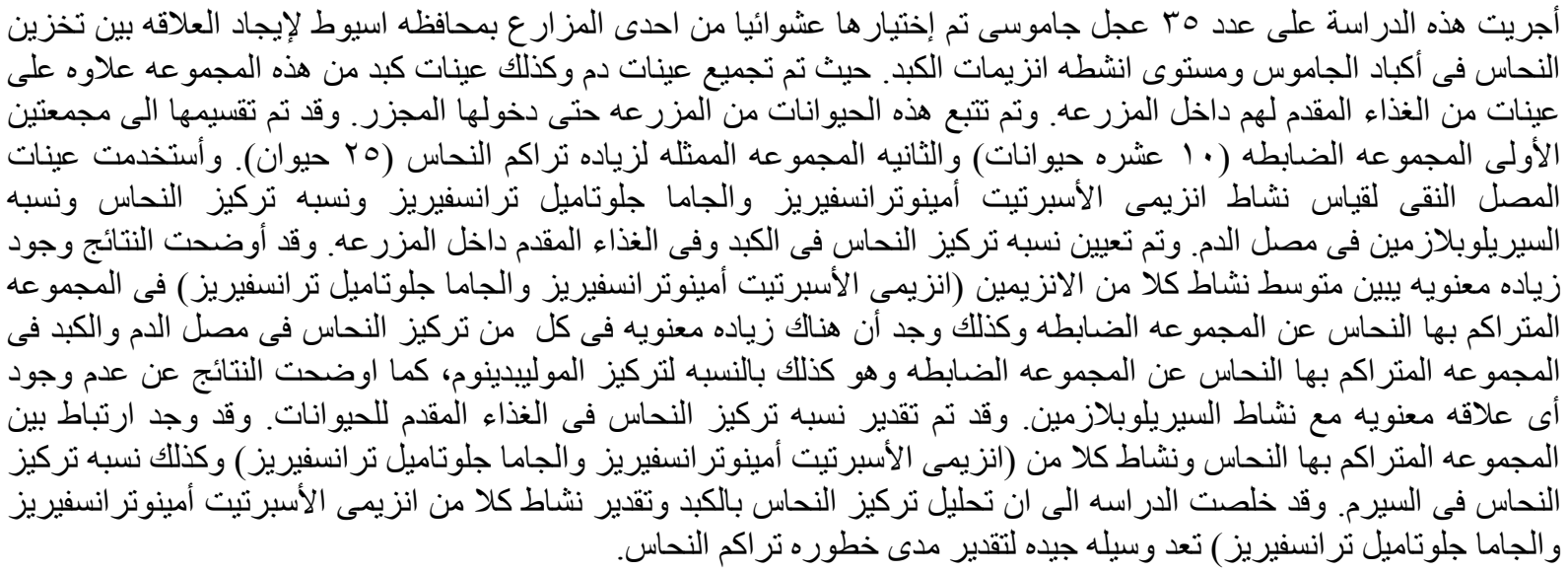

